\title{
Assessment of Numeracy Levels of Mine Workers in South African Chrome Mines
}

Antonie Christoffel Smit

Tshwane University of Technology, smitantonie@gmail.com

Andile Mji

Tshwane University of Technology, mjia@tut.ac.za

Follow this and additional works at: https://digitalcommons.usf.edu/numeracy

Part of the Adult and Continuing Education and Teaching Commons

\section{Recommended Citation}

Smit, Antonie C., and Andile Mji. "Assessment of Numeracy Levels of Mine Workers in South African Chrome Mines." Numeracy 5, Iss. 2 (2012): Article 4. DOI: http://dx.doi.org/10.5038/1936-4660.5.2.4 


\title{
Assessment of Numeracy Levels of Mine Workers in South African Chrome Mines
}

\begin{abstract}
The aim of this paper is to assess and report the numeracy levels of unskilled and semi-skilled workers in three South African chrome mines in order to inform adult education practitioners of the need for greater efforts to educate mine workers. The target population consisted of 1,053 workers; the final sample was 873 participants who voluntarily agreed to partake in the study. The results presented here highlight three main findings: (1) that only 12 individuals (1.4\%) were found to be numerate, (2) that female participants scored better than their male counterparts, and (3) that the numeracy level of participants older than 41 is extremely low.
\end{abstract}

\section{Keywords}

innumeracy, adult numeracy, adult education, educational inequalities, mine workers

\section{Creative Commons License}

(c) (i) (9)

This work is licensed under a Creative Commons Attribution-Noncommercial 4.0 License

\section{Cover Page Footnote}

Antonie Smit is a senior training officer for Anglo American Platinum. His research interests focus on adult education and technology education. He has 14 years experience lecturing vocational subjects at Further Education and Training Colleges.

Andile Mji is professor of Research and Innovation in the faculty of Education, Tshwane University of Technology. His research interests focus on school mathematics and science, learning and teaching, conceptions of and approaches of learning of mathematics, classroom learning environment, and new methodologies in mathematics, science and technology education. 


\section{Introduction}

Mining has been part of South Africa's history since the 19th century. The first prospectors discovered diamonds in 1867 and gold in 1886 (Terreblance 2002). Most jobs in the South African mining industry require manual labour. As a result, these are jobs that are available to illiterate individuals (Hunt Davis 1984; Prinsloo 1999; Rasool 1999). In fact, in the mining industry, high levels of education among the underground workers have never been a requirement. It has been pointed out that "... many employers, including mine owners, regarded education as a disadvantage for most of the jobs they offered" (Allen 2003, p. 31). South Africa's political history has resulted in high levels of poverty and deprivation for its black citizens. For example, under apartheid, black mine workers were denied formal education. These workers are reported to be among some of the most disadvantaged South Africans (Naidoo 2007). In fact, it was reported in 1996 that about $80 \%$ of all mine workers had not acquired education at Grade 7 school level, rendering them functionally illiterate and innumerate (Golding 1996). By 2006 the Sector Education and Training Authority within the Mining Qualification Authority (MQA) reported that of those in employment ten years later, $67 \%$ of mine employees had not achieved a minimum of Grade 7 education. Further, it reported that one in four of the $67 \%$ had not had formal schooling at all (MQA 2006). What this illustrates is that in ten years the literacy and numeracy rate among mine employees has been improved by only 13 percentage points.

The South African mining industry is a critical economic pillar, accounting for $8.8 \%$ of Gross Domestic Product (GDP) (Department of Mineral and Energy, 2008). That portion of the national GDP is generated by 485,900 people in the mining industry, representing approximately $1 \%$ of the citizens. Recently there has been acknowledgement-even among mine owners-that in the 21 st century it is important to educate the corps of illiterate and innumerate workers. This acknowledgement is also a reflection of the precepts of the South African constitution, which specifically endorses the uplifting of any previously disadvantaged populace through-among other things-quality education (Republic of South Africa 1996).

Yet, in spite of these good intentions, a mere 12,731 (2.6\%) of mine employees were registered for literacy and numeracy classes by 2007 (MQA 2008). These figures suggest that mine employees are not-in fact-receiving the quality education that would be part of the uplifting of this disadvantaged population and that could put them on the path to better employment and improved socioeconomic status. Innovative educational programmes and projects aimed at improving mine workers' literacy and numeracy skills will be necessary (Memela and Land 2006). 
While the recognition of adult numeracy as an important research area, after decades of neglect of the topic, has been lauded (see, e.g., Coben 2000), in South Africa the topic is not yet at the forefront of education research. In the South African context, very few studies have focused on adult numeracy in general. This happens in spite of most employers' expectation that workers should be able to at least perform basic mathematical calculations. Without basic numeracy skills, the large numbers of innumerate mine workers cannot be hopeful of better jobs. As noted by Bynner (2004), “... numeracy is a key attribute in gaining and retaining employment" (p. 45). The paucity of studies on this topic has led us to identify numeracy as a problem needing urgent attention. This paper reports on the classification of mine workers, the differences in numeracy between men and women, and the relationship between age and numeracy.

\section{Theoretical Framework}

The term numeracy (quantitative literacy, quantitative reasoning and statistical literacy) was first coined in a report for the United Kingdom Ministry of Education (Crowther Report 1959). Steen (1991) defined numeracy as being “... to mathematics as literacy is to language" (p. 1). Further, Steen (1991) argued that numeracy and literacy represent ".... a distinctive means of communication that is indispensable to civilized life" (p. 1). In fact, in recent decades various authors have formulated definitions for numeracy and innumeracy whose central themes revolve around numeracy being the understanding and application of mathematical principles in order to resolve life's day-to-day challenges (Paulos 1989; Evans 2000; Lindenskov and Wedege 2001; Best 2008). Numeracy in this study is discussed in the context of De Lange (2003):

Mathematical literacy is an individual's capacity to identify and understand the role that mathematics plays in the world, to make well-founded judgments, and to engage in mathematics in ways that meet the needs of that individual's current and future life as a constructive, concerned and reflective citizen (OECD 1999).

Innumeracy has been shown to have a variety of effects on people's lives. For instance, Steen (1991) has identified, among other things, (1) practical effects which have immediate impact on people's daily activities, and (2) professional effects which relate to people's acquisition of the skills required for a given employment situation. In a similar manner, Paulos (1989) has also reported potential effects of numeracy such as (1) inability to control personal finances, (2) inability to make adequate risk assessments, and (3) restricted employment opportunities. Some of the effects of innumeracy have been observed by the first author in his daily dealings with chrome mine workers. In terms of handling their finances, for example, employees often lodge requests for salary advances. This suggests that their salaries run out long before the next pay day. If the advance is 
granted, the subsequent pay cheque amount will be smaller, and the problem then recurs.

South Africa's democracy is in its infancy. Early political developments have involved the implementation of numerous policies. The citizenry benefits from involvement in and understanding of such policies, and there is concern that lownumeracy individuals such as mine workers will not be able to contribute to the public discourse because of an inability to understand quantitative information (Steen and Madison 2001). Additionally, as mentioned previously, employment opportunities for innumerate individuals confined to manual labour are extremely limited (see, e.g., Bynner and Parsons 1997).

The intent of this paper is to contribute to the body of knowledge about the status of numeracy among chrome mine workers. Specifically, this assessment can alert adult education practitioners of the need for greater efforts to educate unskilled workers. Also it can help with the development of programmes specifically suited to their circumstances. This intent is consistent with the view that "... society today ought also to value a numerate citizenry and to strive to increase the functional numeracy of the population" (Sowey 2002, p. 1).

\section{METHOD}

\section{Participants}

The target population consisted of 1,053 mine workers from three chrome mines in South Africa. This population was comprised of only those workers classified as either unskilled or semi-skilled. Mine workers in the target population were informed about the study, and it was clearly explained that their participation was not compulsory. It was further stressed that the information they provided would be used only for research purposes. We emphasised this point as some workers expressed anxiety that any information they provided would end up with mine managers. The final sample was $873(82.9 \%)$ participants who voluntarily agreed to participate in the study.

\section{Instrument and procedure}

The instrument used in the study was a standardised, commercially available achievement test developed and copyrighted by Media Works. The Media Works instrument for Numeracy (MWiN) was chosen because the company specialises in adult basic education remedial courses. This company provides its adult basic education and training services to the three chrome mines that were part of our study. Media Works has used the instrument in the mining industry over a long period. They have in fact indicated that results from different studies have been trustworthy and consistent. Based on this, we accepted the validity and reliability of the MWiN a priori. The choice of the instrument was based on the advice that 
when reliable and valid instruments are commercially available, it is sensible to use them (Welman, Kruger, and Mitchell 2005; Cohen, Manion, and Morrison 2007).

The MWiN comprises two parts. The first part obtains participants' demographic information such as age, gender, and highest level of schooling. The second part is a standardised academic achievement test intended to assess the numeracy of adult learners. This test is designed to focus on questions that relate to everyday situations. The test scoring system categorizes test takers into four levels of competence, Level 1 being the lowest and Level 4 being the highest. There are 24 questions on the test, worth a total of 80 points: ABET Level 1 is worth 15 points, ABET Level 2 is worth 15 points, ABET Level 3 is worth 25 points and ABET Level 4 is worth 25 points. Participants had to answer all 24 questions. For classification purposes, participants scoring between 0 and 15 points were assigned to ABET Level 1. Those who scored between 16 and 30 points were assigned to ABET Level 2. Participants scoring between 31 and 55 were assigned to ABET Level 3, and those scoring 56 and higher were assigned to ABET Level 4.

Table 1

Example questions at the four ABET levels

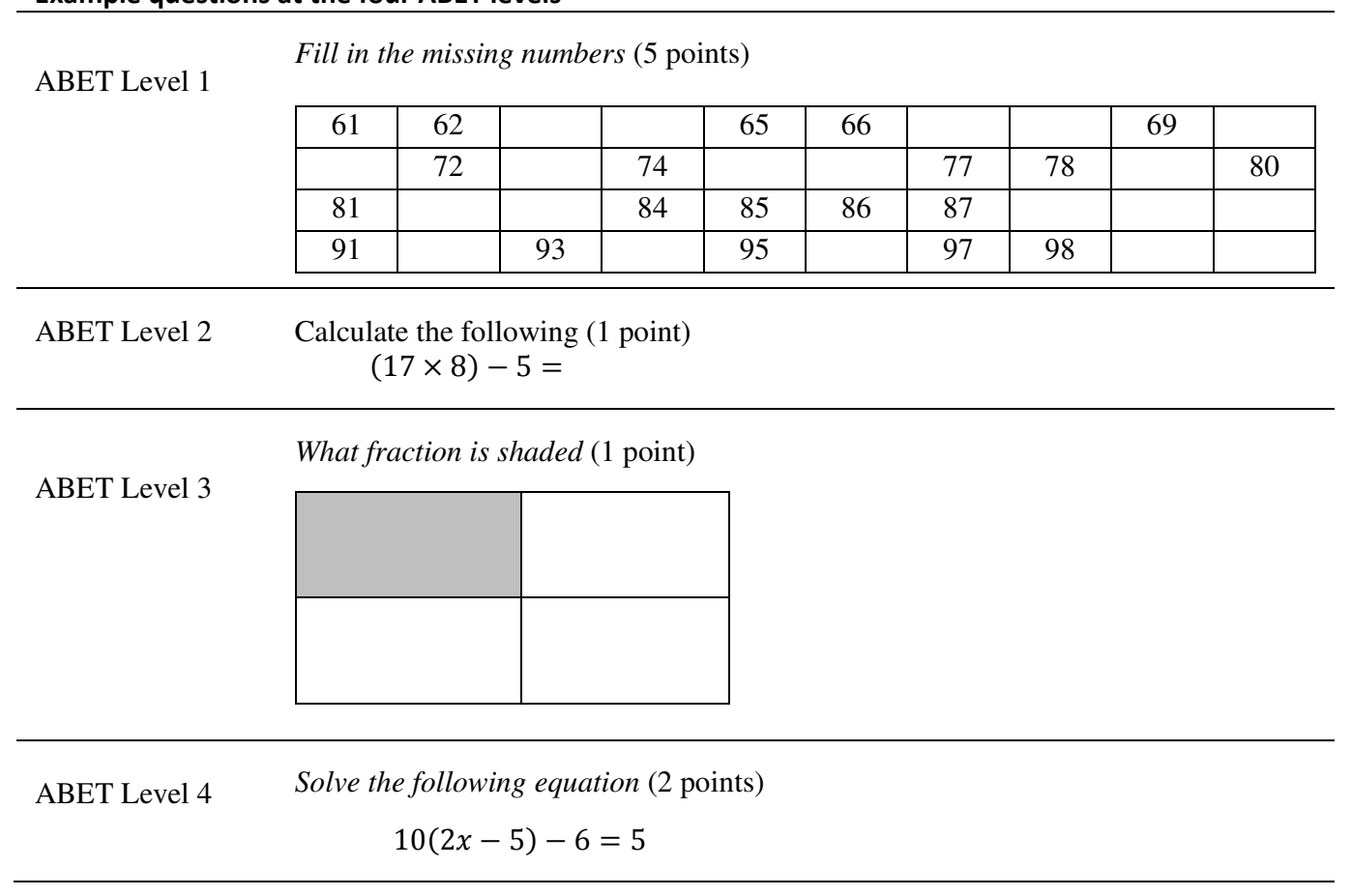


ABET Level 1 covers computations relating to addition and subtraction at the third-grade level. ${ }^{1}$ ABET Level 2 covers grade-5 level concepts of multiplication and division as well as concepts covered in ABET Level 1. ABET Level 3 focuses on grade-7 level concepts such as fractions and areas of figures and includes concepts covered in ABET Level 1 and 2. ABET Level 4 covers grade-9 level concepts such as percentages, ratios, averages, volume, and solving equations as well as concepts covered in previous levels. Examples are shown in Table 1.

The MWiN was administered in the fall of 2010 during normal class time for adult learners. In each of the three chrome mines, Adult Basic Education and Training facilitators were requested to administer the instrument. The first author managed and controlled the entire process. All the facilitators, including the first author, were familiar with the MWiN and had been trained by Media Works on teaching numeracy to adult learners and addressing queries participants may have had during the administration of the instrument. The test is a paper and pencil format with questions also digitally projected onto a screen. The screen projection has both an English question as well as a translation in Zulu (a language that most workers understand). One of the functions of the facilitators is to move around the classroom and assist participants who need help. For instance, facilitators may explain what is required in the language of the participants; however, they may not provide answers. This has been found to be useful especially for participants who were not functionally literate.

\section{Results}

Participants were $746(85.5 \%)$ men and $127(14.5 \%)$ women. Their ages ranged between 19 years and 62 years $(M=$ 42.2 years; $\mathrm{SD}=11.3$ ). In terms of schooling, $465(53.3 \%)$ indicated that they had completed Grade 7 or less.

Table 2

\begin{tabular}{lcc}
\multicolumn{3}{l}{ Respondent numeracy-level classification } \\
\hline Numeracy Classification & $N$ & Percentage \\
\hline ABET Level 1 & 518 & 59.3 \\
ABET Level 2 & 343 & 39.3 \\
ABET Level 3 & 12 & 1.4 \\
ABET Level 4 & 0 & 0 \\
\hline
\end{tabular}
Three hundred and forty-one (39.1\%) indicated that they had completed Grade 10 to Grade 12. With respect to scores obtained from the MWiN however, it is noteworthy that $98.6 \%$ of the participants were classified to be operating at ABET Level 2 or less (see Table 2). In effect, the table reveals that only 12 participants demonstrate functional numeracy based on the South African definition. Further analysis revealed that the 12 participants at ABET Level 3 were women with ages ranging from 21 years to 33 years $(\mathrm{M}=25.2 ; \mathrm{SD}=3.2)$ and that they had completed schooling through Grade 12.

\footnotetext{
${ }^{1}$ The grade levels described here are of the South African school system that starts from grade-R to grade-12
} 
An analysis of variance (ANOVA) was computed to determine whether differences with respect to gender could be established. Table 3 shows the mean and standard deviation of scores obtained in each level according to gender. The table also includes Levene's test of homogeneity of variance, which indicates that variance was not homogenous for ABET Level 1 scores. With respect to ANOVA, statistically significant differences were established at all levels; $F$ $(1,871)=20.46, p<0.05$ (ABET Level 1$), F(1,870)=27.62, p<0.05$ (ABET Level 2), and $F(1,870)=13.08, p<0.05$ (ABET Level 2). Table 2 shows that the differences were due to women obtaining higher scores than men.

Table 3

Distribution of mean and standard deviation according to gender and Numeracy classification together with the Levene's test of homogeneity of variance

\begin{tabular}{ccccccccc}
\hline $\begin{array}{c}\text { Numeracy } \\
\text { Classification }\end{array}$ & Gender & $N$ & $M$ & $S D$ & $\begin{array}{c}\text { Levene } \\
\text { Statistic }\end{array}$ & $d f 1$ & $d f 2$ & $p$ \\
\hline \multirow{2}{*}{ ABET Level 1 } & Men & 746 & 6.22 & 4.6 & 7.88 & 1 & 871 & $.005^{*}$ \\
& Women & 127 & 8.21 & 4.3 & & & & .089 \\
ABET Level 2 & Men & 745 & 2.90 & 4.0 & 2.89 & 1 & 870 & \\
& Women & 127 & 4.94 & 3.9 & & & & .535 \\
ABET Level 3 & Men & 745 & 2.25 & 5.0 & .39 & 1 & 870 \\
& Women & 127 & 4.02 & 5.8 & & & & \\
\hline
\end{tabular}

$* p<0.05$

Multivariate analysis of variance (MANOVA) was computed to determine mean differences between age groups and ABET levels. In this instance, the null hypothesis that the observed covariance matrices were equal across groups was rejected. This was because Box' $M$ was statistically significant [Box' $M=669.75$, $F(12,1205893.02)=55.45, p<0.05]$. The multivariate test of the model was however statistically significant (Wilks' $\lambda=0.74, F(6,1734)=46.16$, partial eta squared $=0.14$, power $=1.00$ ). Tests revealed statistically significant differences between age groups and the three ABET levels. The calculated statistics were $F$ $(2,869)=93.37$, partial eta squared $=0.18$, power $=1.00($ ABET Level 1$) ; F(2$, $869)=146.02$, partial eta squared $=0.25$, power $=1.00($ ABET Level 2$) ; F(2$, $869)=55.68$, partial eta squared $=0.11$, power $=1.00($ ABET Level 3$)$.

A post hoc analysis was computed to establish the specific means that were different. With respect to ABET Level 1 and ABET Level 2, Scheffe's post hoc analysis revealed that the differences were among each of the age groups (see marginal means in Table 4). That is, the mean scores of each age group - Lowest through 29 years, 30 years through 40 years and 41 years through Highest - were different from each other. However, with regard to ABET Level 3, the difference was between the age group 41 years through Highest and the other two age groups. 
Table 4

Marginal means of the different age groups against numeracy classification

\begin{tabular}{cccccc}
\hline & & & \multicolumn{3}{c}{$95 \%$ Confidence Interval } \\
$\begin{array}{c}\text { Numeracy } \\
\text { Classification }\end{array}$ & Age Group & Mean & Std. & $\begin{array}{c}\text { Lower } \\
\text { Bound }\end{array}$ & $\begin{array}{c}\text { Upper } \\
\text { Bound }\end{array}$ \\
\hline ABET Level 1 & Lowest through 29 years & 9.56 & .31 & 9.96 & 10.16 \\
& 30 years through 40 years & 7.78 & .32 & 7.16 & 8.41 \\
& 41 years through Highest & 4.93 & .19 & 4.56 & 5.30 \\
& & & & & \\
ABET Level 2 & Lowest through 29 years & 6.22 & .26 & 5.72 & 6.72 \\
& 30 years through 40 years & 4.83 & .27 & 4.31 & 5.35 \\
& 41 years through Highest & 1.50 & .16 & 1.19 & 1.81 \\
& & & & & \\
ABET Level 3 & Lowest through 29 years & 4.879 & .35 & 4.19 & 5.57 \\
& 30 years through 40 years & 4.148 & .37 & 3.43 & 4.87 \\
& 41 years through Highest & 1.043 & .22 & 0.62 & 1.47 \\
\hline
\end{tabular}

\section{Discussion}

The results presented in this study have highlighted three main findings. These findings relate to the classification of mine workers, to establishing whether differences existed between male and female respondents, and to determining whether age had an effect on numeracy. Classification of participants from the three chrome mines indicated that only 12 individuals $(1.4 \%)$ were numerate. Analysis of variance also revealed that female participants obtained better scores than their male counterparts. Further, multivariate analysis of variance indicated that, in general, the older participants (41 years and older) obtained the lowest scores in the standardised academic achievement test. A majority of these older participants were men. Perhaps these results may be explained by the fact that most women were younger and had higher school qualifications than men. Traditionally the mining industry has been a male-dominated workplace. However, more companies in South Africa, including those governed by the Mining Charter, have recently been forced by legislation to increase the number of women in the workplace. The hiring of small numbers of women with high levels of schooling likely contributes to reported overall increase in numeracy levels of mine employees.

The results reported here should be a cause for concern among mine authorities. As mining is labour intensive, men will continue to make up the majority of the workforce. The recent trend to employ women with higher education levels to improve the literacy figures cannot be hidden. We are hopeful that the research reported in this paper will inform adult education practitioners of the need to design proper methodology to improve mine workers' numeracy levels. Perhaps the study will also prod mine owners to think about offering incentives for those mine workers who attend remedial classes. Such incentives 
could be monetary or in the form of time off from work. It may be important to note that there is currently one numeracy training site, and mine workers must travel up to 70 kilometres to reach the venue. Mine owners should consider establishing numeracy training venues closer to where employees reside.

The results of this assessment highlight the very low levels of numeracy competence among chrome mine workers. Innumerate individuals do not have the same quality of life as numerate people and are therefore at a disadvantage. To improve the socio-economic status of its workers, the mining industry needs to devote time and effort to improving numeracy levels of its employees. The importance of improving mine workers' numeracy cannot be overemphasised. In fact, such improvement may not only be beneficial to mine workers' lives but it may positively impact their children's education and society in general. Lusardi (2012, p. 10) has raised the fact that findings from both the United States and other countries:

... regarding the level of numeracy is very low and particularly severe among some already vulnerable groups in the population, such as the elderly, women, and those with low educational attainment. This is problematic because numeracy has been found to be linked to financial decision making, and many governments and employers around the world are increasingly shifting the responsibility for saving, investing, and borrowing onto individuals.

If mine workers are numerate, they may gain improved understanding of financial matters. This is an important issue because it is argued that that people must be able to make well-informed financial decisions in an increasingly risky and globalized marketplace (Lusardi and Mitchell 2011). Well-informed financial decisions are important in the South African context because this is a country with a low investment ethic. For example, it was recently reported that forty percent of South Africans are saving less now than they did six months ago, and that "[This] is not great considering [South Africans] are not great savers anyway," according to Lynette Nicholson, chief researcher of Old Mutual (The Citizen, 2011).

\section{Limitations}

It is worth pointing out that the findings presented in this study may not be generalised to all South African mine workers as the sample was not necessarily representative of all mines. We acknowledge that numeracy statistics obtained among this group of mine workers may have been affected by their literacy ability. Some mine workers who were part of the assessments may not have properly understood some of the numeracy questions. Nonetheless, we are of the view that this study is critical in exposing what is currently happening among chrome mine workers. Also the study should provide baseline information that will assist in planning by those charged with addressing mine workers' numeracy competency. 


\section{References}

Adult Financial Literacy Group. 2000. Report to the Secretary of State for Education and Employment. London: Department for Education and Employment.

Allen, V. L. 2003. The history of black mine workers in South Africa. Volume II. Dissent and repression in the mine compounds 1948 - 1982. West Yorkshire: The Moore Press.

Best, J. 2008. Birds - dead and deadly: Why numeracy needs to address social construction. Numeracy, 1 (1): Article 2. http://dx.doi.org/10.5038/1936-4660.1.1.6

Bynner, J. 2004. Literacy, numeracy and employability: Evidence from the British birth cohort studies. Literacy and Numeracy Studies, 13 (1), 31 - 48.

$\longrightarrow$, and S. Parsons. 1997. It doesn't get any better: The impact of poor basic skills on the lives of 37 year olds. London: The Basic Skills Agency.

Coben, D. 2000. Numeracy, mathematics and adult learning. In Adult Numeracy Development: Theory, research, practice, ed. I. Gal, 33-50, Cresskill, NJ: Hampton Press.

Cohen, L., L. Manion, and K. Morrison. 2007. Research methods in education. London: Routledge Falmer.

Crowther Report. 1959. 15 to 18: A report of the Central Advisory Committee for Education. London: HMSO.

De Lange, J. (2003). Mathematics for literacy. In Quantitative literacy: Why numeracy matters for schools and colleges ed. B.L. Madison and L.A. Steen, 75-89. Proceedings of the National Forum on Quantitative Literacy held at the National Academy of Sciences in Washington, D.C. on December 1-2, 2001. Princeton NJ: National Council on Education and the Disciplines.

Department of Minerals and Energy (South Africa). 2008. Mine health and safety inspectorate annual report 2007/2008. Retrieved June 27, 2012 from http://www.info.gov.za/view/DownloadFileAction?id=93533

Evans, J. 2000. Adults' mathematical thinking and emotions: A study of numerate practices. London: Routledge Falmer.

Golding, M. P. (1996). The political, economic and social influences on South African mining. International Precious Metals forum, London.

Hunt, D. R. 1984. The administration and financing of African education in South Africa, 1910 - 1953. In Apartheid and education: The education of black South Africans, ed. P. Kallaway, 127-138. Johannesburg: Raven Press.

Lindenskov, L. and T. Wedege. 2001. Numeracy as an analytical tool in mathematics education research. Roskilde: Roskilde University, Center for Research in learning mathematics, Roskilde, Publication No. 31.

Lusardi, A. 2012. Numeracy, financial literacy, and financial decision-making. National Bureau of Economic Research (NBER), Working Paper 17821. Retrieved March 18, 2010 from http://www.nber.org/papers/w17821 
- and O. S. Mitchell. 2011. Financial literacy around the world: An overview. Journal of Pension Economics and Finance, 10: 497-508. http://dx.doi.org/10.1017/S1474747211000448

Memela, B., and S. Land. 2006. Isicathamiya sase Stoffelton: Reflections on an education for democracy project. Journal of Education, 39, 47-62.

Mining Qualification Authority. 2006) Adult basic education and training statement of intent.

Mining Qualification Authority. 2008. Annual report 2007/2008. Retrieved June 27, 2012 http://www.mqa.org.za/siteimgs/Anual\%20reports/MQA\%20Annual\%20Report\%200708\%20\%28Screen\%29.pdf

Naidoo, J. 2007. Leading and managing adult basic education and training centres: A comparative case study of two ABET Centres in KwaZulu-Natal. Retrieved April 05, 2010 from http://researchspace.ukzn.ac.za/xmlui/

Paulos, J. A. 1989. Innumeracy: Mathematical illiteracy and its consequences. New York: Hill and Wang.

Prinsloo, M. 1999. Literacy in South Africa. In Literacy: An international handbook, ed. D. A. Wagner, R. Venezky, and B. V. Street (Eds.), 418-423. Boulder, CO: Westview Press.

Rassool, N. 1999. Literacy for sustainable development in the age of information. Clevedon: Multilingual Matters Ltd.

Republic of South Africa. 1996. The constitution of the Republic of South Africa. Johannesburg: Typeface Media.

Steen, L. A. 1991. Numeracy. In Literacy: An overview by fourteen experts, ed. S. R. Graubard, 211-231). New York: Hill and Wang.

- and B. L. Madison. 2011. Reflections on the tenth Anniversary of Mathematics and Democracy. Numeracy, 4 (1): Article 1. http://dx.doi.org/10.5038/1936-4660.4.1.1

South African Qualifications Authority. 2008. The impact of the critical outcomes o curriculum, pedagogy and assessment in ABET. Retrieved February 08, 2009 from http://www.saqa.org.za

Sowey, E. R. 2002. The getting of wisdom: Educating statisticians to enhance their clients' numeracy. In Proceedings of the Sixth International Conference on Teaching Statistics, ed. B. Phillips. Voorburg, The Netherlands: International Statistical Institute.

Terreblanche, S. 2002. A history of inequality in South Africa, 1652 - 2002. Pietermaritzburg: University of Natal Press.

The Citizen. 2011 (November 24). 40 Percent in SA saving less: survey The Citizen, Business News. Retrieved November 25, 2011 from http://www.citizen.co.za Welman, J. J., S. J. Kruger, and B. Mitchell, B. 2005. Research methodology, 3rd ed. Cape Town: Oxford University Press. 